\title{
The Past as a Public Good
}

\author{
Sandra J. Peart
}

Published online: 20 March 2012

(C) Springer Science+Business Media, LLC 2012

At least since Adam Smith's time, economists have acknowledged the benefits associated with specialization within the academy and within economics. Notwithstanding this appreciation, they fail to appreciate the benefits associated with knowing their past. The costs of walking away from that past in economics have been substantial and have been substantially underappreciated. This paper makes a case for studying, learning and teaching our past in economics, for reuniting economics with its more literary, historical and philosophical roots. It makes the case for specialization and then tradetrade amongst economists and amongst disciplines.

Indeed, colleagues in political theory, American studies, literature and so on with an interest in markets and incentives, and economists have a great deal to talk about together. Economists have a place in those conversations and they have too readily ceded that place. In their absence, others have stepped up to read, write and teach about the past of economics. That has not always been good for economics as a discipline or perhaps more significantly for the world of policy-making.

It is well known that economics became much more technical in the last three decades. In so doing it crowded out more historically inclined courses and analyses such as the history of the discipline, economic history, history of financial institutions, or development economics, the sorts of analyses that Austrian economists, constitutional political economists or historians of economics use.

Debates then began about the usefulness (or not) of the history of economic thought and the right "place" for its study. Some argued for history of economics to be located in history and philosophy of science departments. Others simply took the position that history (of the discipline) was unnecessary; since economics progressed from wrong to right ideas, the study of old (wrong) ideas served no useful

\footnotetext{
S. J. Peart $(\bowtie)$

Jepson School of Leadership Studies, University of Richmond, Richmond, VA 23173, USA

e-mail: speart@richmond.edu
}

purpose. The history of the discipline subsequently declined precipitously as subject matter for graduate programs. ${ }^{1}$ This was very much a market-driven response to developments in economics training. For Ph.D. candidates to obtain employment, they needed to be technically trained, so soon there was little room in the curriculum for anything else.

A consequence of these developments is that the private returns to specializing in the history of the discipline are now quite low in economics. The public returns - the returns within the academy and for society at large - are, however, much higher than the private. As we in economics say, the past is a public good. All can consume a "history" (whether a correct one or not) once a "history" is published. Public goods are characteristically under-provided by the market. As Levy and Peart have argued, this may be especially true for the past of economics. What has been the cost of under-provision? Levy and Peart argue that the cost is larger than once thought. The paper next presents three examples of how the past has been badly misconstrued in the absence of good historical analysis within economics.

\section{The Dismal Science Story ${ }^{2}$}

If economists fail to teach the past of economic ideas, someone else will. In recent experience, academics who

\footnotetext{
${ }^{1}$ This history is well documented; see C. Goodwin, "History of economic thought," in S. Durlauf and L. Blume (eds.), The New Palgrave dictionary of economics online (London: Palgrave Macmillan): http:// www.dictionaryofeconomics.com/article?id=pde2008_H000174 and S. J. Peart, "The education of economists: Teaching what economists do," Journal of Economic Education, vol. 25 (2004): 81-87.

2 J. Persky, "Retrospectives: A dismal romantic," Journal of Economic Perspectives, vol. 4 (1990): 165-172; D. M. Levy, How the dismal science got its name: Classical economics and the ur-text of racial politics (Ann Arbor: University of Michigan Press, 2001); and S. J. Peart and D. M. Levy, The "Vanity of the philosopher": From equality to hierarchy in post-classical economics (Ann Arbor: University of Michigan Press, 2005).
} 
are hostile to Adam Smith or markets have taught the past of economic thought. Many readers know the phrase "the dismal science" and know that it pertains to economics. Until quite recently, the historical "record" held that the phrase was given to Malthusian-style economics of the nineteenth century which, so the story goes, cheerfully predicted widespread misery and starvation. Economics became equated with hard-hearted, unfeeling profiteering at the expense of the poor (think of Scrooge in A Christmas Carol); the discipline became almost inextricably linked with selfishness and misery.

The fact, however, is that Robert Malthus never predicted or advocated misery; instead he believed that, as long as poor people knew they were responsible for raising their children, they would delay marriage until they could afford to raise the children that would be forthcoming. Malthus had great faith in ordinary people who, knowing the regularity of the laws of nature, were able to govern themselves.

Consider two accounts of the history of economics. The standard account suggests that economics became the "dismal science" because of an avowedly unrealistic view of human nature that denied the possibility of human improvement. ${ }^{3}$ Here dismal science ought to be read as the "sorrowful science" because economists were committed to a fixed world of misery. They opposed schemes for improvement and favored markets instead.

In an alternative account-one which Peart and Levy suggest is accurate, though less widely known-economics became the dismal science because of an avowedly unrealistic view of human nature which denied that races are inherently different. Here dismal science ought to be read as the "Negro science" because economists were committed to a fixed, race-blind human nature. Economists supposed that people are equally competent. They opposed racial slavery, and they favored markets instead.

How much would a representative economist be willing to pay to learn that the alternative account of our history is accurate, and the standard account is therefore a distortion of our past? If a positive price answers this question, then we have the possibility of a substantial divergence between private and social considerations.

Here is the passage in which Thomas Carlyle first called economics the "dismal science". We underline the portion quoted in the Oxford English Dictionary, which contains nothing to suggest that "dismal science" epithet was applied to political economy for its anti-slavery position. The full passage clarifies that this anti-slavery stance was what in

\footnotetext{
${ }^{3}$ Among the many history of economic thought textbooks that present this view are R. L. Heilbroner, The worldly philosophers (New York: Simon and Schuster, 1961), 61; R. B. Ekelund and R. F. Hébert, A history of economic theory and method, third edition (New York: McGraw-Hill, 1990), 172; and J. Oser and S. Brue, The evolution of economic thought, third edition (San Diego: Harcourt Brace, 1988), 91.
}

fact drew Carlyle's criticism. ${ }^{4}$ The selective quotation in the $O E D$ highlights what economists have lost by forgetting our past, the cost paid for giving up competence in the history of our discipline:

Truly, my philanthropic friends, Exeter Hall Philanthropy is wonderful; and the Social Science-not a "gay science," but a rueful-which finds the secret of this universe in "supply-and-demand," and reduces the duty of human governors to that of letting men alone, is also wonderful. Not a "gay science," I should say, like some we have heard of; no, a dreary, desolate, and indeed quite abject and distressing one; what we might call, by way of eminence, the dismal science. These two, Exeter Hall Philanthropy and the Dismal Science, led by any sacred cause of Black Emancipation, or the like, to fall in love and make a wedding of it,-will give birth to progenies and prodigies; dark extensive moon-calves, unnameable abortions, wide-coiled monstrosities, such as the world has not seen hitherto! ${ }^{5}$

The standard version of the history of the discipline, the version supported by the $O E D$ reference underlined above, suggests that we are "dismal" because we deal with scarcity, supply and demand. The full quotation above shows that the reason Carlyle called economics "dismal" is that economists advocate markets as opposed to slavery, they reduce "the duty of human governors to that of letting men alone". If we remember that the Act of Emancipation (the "sacred cause") was a political bargain, the full quotation reveals that the debate concerns self-government in both private and public dimensions.

Fifteen years later, the issue of race and hierarchy returned to public attention in Britain with a vengeance. The real meaning of the Carlyle-Mill debate became clear during the "Governor Eyre Controversy" of 1865.The controversy was triggered by a seemingly trivial event in the British colony of Jamaica. On Wednesday the police came to enforce the warrants. Stones were thrown at the police and shooting began. The island's Governor, Edward James Eyre, imposed martial law and called in the army to restore order. By the time the army was done, over 400 Jamaicans were dead, and thousands were homeless. Britons were horrified by the methods of state terror, including flogging with wire whips and the use of military courts to deny

\footnotetext{
${ }^{4}$ [T. Carlyle], "Occasional discourse on the negro question," Fraser's Magazine for Town and Country, vol. 40 (1849): 670-79.

${ }^{5} \mathrm{~J}$. S. Mill responded quickly because he feared that the progress of American emancipation might be impeded by Carlyle's prestigious position in the literary world. See [J. S. Mill], "The Negro question," Fraser's Magazine for Town and Country, vol. 41 (1950: 24-31. The Eyre Controversy is examined in detail, in D. M. Levy and S. J. Peart, "The Secret History of the Dismal Science," http://www.econlib.org/ library/Columns/LevyPeartdismal.html, 2001-2002.
} 
civilians their rights. Among the dead was George Gordon, a Baptist minister and member of Jamaica's legislature.

In Britain, evangelical anti-slavery forces formed the Jamaica Committee to protest the Governor's actions and demand an investigation. The members of the Jamaica Committee included a host of worthies not usually associated with evangelical Christianity. As head, the members unanimously chose John Stuart Mill. On the other side, the Eyre Defense Fund was led by Thomas Carlyle, aided by John Ruskin. The two sides lined up with classical political economists and scientists-Mill, John Bright, Henry Fawcett, J. E. Cairnes, Herbert Spencer, T. H. Huxley, and Charles Darwin - on the Jamaica Committee; and Thomas Carlyle, Charles Dickens, Alfred Tennyson, and John Ruskin defending Governor Eyre's massacre of former slaves. Yet as a matter of historical record, the roles of the economists and the poets in the Eyre massacre have largely been forgotten. ${ }^{6}$

The "dismal science" phrase was indeed applied to economics by Thomas Carlyle to denigrate economics. But Carlyle's problem in 1849 was not with Malthus but rather with markets, generally, with people being able freely to enter into contracts to work (or not). The alternative that Carlyle proposed was the re-enslavement of the west-Africans in Jamaica.

This is one story that has been badly told by those who have taught the past of economics.

\section{Soviet Growth in Economics Textbooks}

A second major case of misplacing the past has to do with economists' analysis of Soviet-US growth rates during the Cold War. American economics textbooks were extraordinarily optimistic about Soviet growth and they sometimes re-wrote the past over time to suit this optimism. Instead of remembering the public choice insights of economists such as David Hume, textbook authors seem to have supposed that were their advice heeded, the economy would efficiently implement the planner's goal of growth. There would be no waste and the impoverishment of the present Soviet citizens would benefit future citizens.

\footnotetext{
${ }^{6}$ Of course, it took some time for the memory to be erased. In a lecture published the year before his retirement, Alfred Marshall questioned whether the comparative reputations of Mill and Carlyle would stand if people would read Mill in conjunction with Carlyle's defense of Eyre: "If anyone will read Mill's Autobiography, his essays 'On Socialism,' published in the Fortnightly Review from 1879, or even his discussions of progress and of the functions of Government in the last chapters of Books IV and V. respectively of his Political Economy, and compare them with Carlyle's pamphlet on Shooting Niagara, he will see that the popular opinion as to the generosity of Carlyle's temper and the hardness of Mill's is incorrect. He may even perhaps think that it should be inverted." A. Marshall, "The social possibilities of economic chivalry,” Economic Journal, vol. 17 (1907): 18.
}

The collapse of the Soviet Union surprised many students of economics in part because its economy had long been portrayed in textbooks as a viable alternative to democratic capitalism. For years, textbooks had shown that the Soviet economy was growing faster than the US and many concluded that Soviet citizens would soon enjoy a higher standard of living than Americans.

Levy and Peart systematically examine the treatment of Soviet growth in American economics textbooks from 1960-1980. ${ }^{7}$ They find that estimates of Soviet growth were high in the most successful textbooks and that the range of uncertainty associated with the estimates was understated. The treatment of Soviet growth in successive editions of American economics textbooks reveals an over-confidence in the estimates of Soviet growth which appeared as an asymmetric response to past forecast errors. The textbooks report faster Soviet output growth combined with a constant ratio of Soviet-US output. Even after 20 years of so-called faster growth, the unchanged actual ratio of Soviet-US output elicits no comments from the authors.

Of course, it is now well known that the Soviet economy was growing less quickly than once thought. Yet far less appreciated is the fact that accounts of Soviet "growth" emerged and changed over time in successive editions of American economics textbooks. This trust in the future and skepticism about the past formed the basis of a standard Soviet-era joke: "Under Communism, the Poles are fond of saying, only the future is certain; the past is always changing." endogenous past" project.

Why were the authors of important textbooks of the 1960s and 1970s so confident about Soviet economic growth that evidence of model failure was repeatedly blamed on events outside the model's control? The optimism arose at least in part from forgetting past insightsthose of Adam Smith and David Hume, who would never have presumed that the Soviet and the US economies were essentially the same despite institutional differences. So, Samuelson's text pioneered the use of the Production Possibility Frontier (PPF) as the means by which to compare different economies. The PPF bought elegance by abstraction and collapsed each society into a two-dimension production possibility set. Of course, if an omitted variable was important in only one of the societies being compared, the model's predictions would be incorrect.

That assumption - that economic analysis applied across wide institutional differences - meant that the country which invested more as a share of GDP would also grow more

\footnotetext{
${ }_{7}^{7}$ D. M. Levy and S. J. Peart, "Soviet growth and American textbooks: An endogenous past," Journal of Economic Behavior and Organization, vol. 78 (2011): 110-25, contains the details.

${ }^{8} \mathrm{G}$. W. Nutter, The strange world of Ivan Ivanov, New York and Cleveland: World Publishing (1969), 22.
} 
quickly. The point to add to this is that tools are chosen by researchers and can be changed. Yet after two decades of nonconfirming evidence these predictions were not abandoned.

In 1961, Samuelson devised a graph which provides a rough and ready forecast of Soviet and American growth trajectories. Using different assumptions about Soviet and American growth rates, Samuelson projects when the Soviet economy will overtake the US economy. His first projection (a max-min overtaking point) is based on the maximum respectable Soviet growth assumption and the minimum respectable American growth assumption. The second date, a max-max prediction, is more cautious about when the overtaking will occur: it uses the maximum Soviet growth assumption and the maximum American growth assumption. The graph inspires confidence because it presents a range of uncertainty attached to the growth estimates (Fig. 1).

From 1961 through 1973 the ratio of US to Soviet output is constant at $100 / 50$. The claim of considerably faster Soviet growth made by the graph is juxtaposed with an unchanging ratio of real output levels notwithstanding the obvious fact that sustained faster growth would have to imply a change in the ratio. In fact, Samuelson at one point silently re-based the graph (moving its origin to the right) so that the 1960 ratio had to have been recognized to be something below 100:50.

\section{Financial History}

The damage caused by the belief that AAA-rated investments were as secure as those offered by the US government is still being tallied. We now know that there was significant shopping for ratings that caused a devastating upward bias in the ratings $(64,000$ AAA ratings on securitized assets in 2008). The most interesting question remaining is why the regulators ever did trust the rating agencies?

What was apparently forgotten at great cost is that there was a time when the ratings agencies were not trusted. When they became part of the regulatory establishment in the 1930s it was commonly known and understood that ratings agencies had the strong incentive to provide upwardly biased ratings. What was trusted back then was a statistical procedure which bounded the influence of an individual rating
Fig. 1 Samuelson and the future of capitalism
830

CURRENT ECONOMIC PROBLEMS

\section{America leads Russia, but will the gap narrow?}

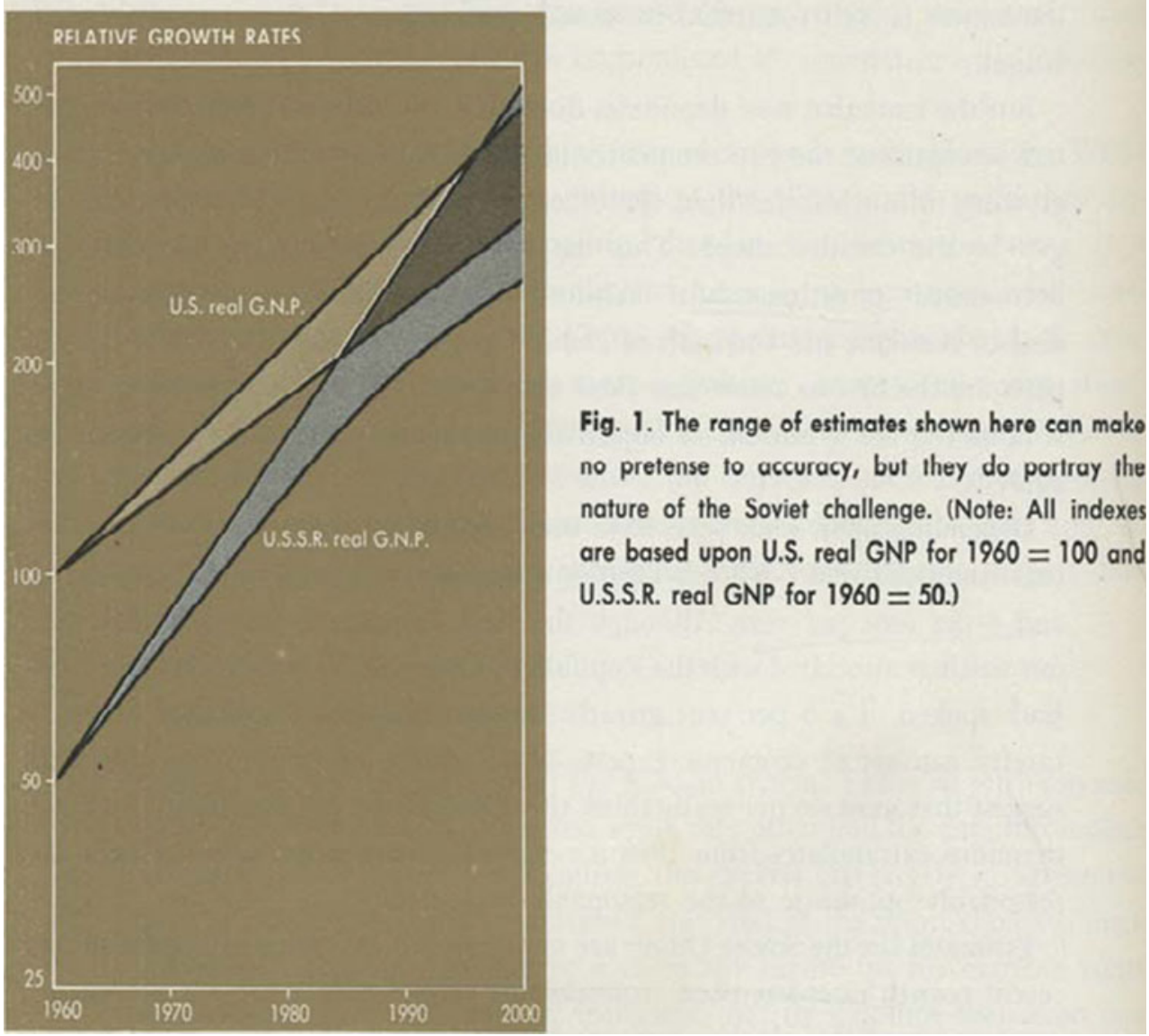


agency and attenuated the consequences of the bias. The term of art was a "composite" of the ratings. But the wisdom which underlay this prudential estimation procedure was lost between the time of establishment (1930s) and the disasters of recent memory. ${ }^{9}$

\section{Lessons from the Past}

What lessons can we draw from these three examples? First, from the Dismal Science story, we learn that if economists cede competence to speak about our past and present, someone with animus towards economics may develop a narrative for us. This narrative may present a caricature of Adam Smith as an individualist and Malthus as a precursor to Spencer. It may fail to appreciate that James Buchanan had much in common with John Rawls, whom he knew, and with David Hume.

If economists give up competency in the past of economics, someone else might take up and promote a "history." When economists then try to correct that "history"-as Levy and Peart have done - they might then be accused, by those who hold to the view that markets are grungy, the for-profit world is morally suspect, and market-oriented folks are money grubbing, of "trawling for evidence" - as Levy and Peart have been accused.

Second, why were economists so optimistic about Soviet growth? We learn from studying this episode that institutions matter and neglecting them may lead to mistakes. Textbook authors such as McConnell (1960-1990) and Samuelson (1961-1973) adopted as a starting point the presumption that the Soviet and the US economies were essentially the same despite enormously important institutional differences (Levy and Peart, op. cit., 2011). Technical devices used by economists masked these differences. The PPF collapsed each society into a two-dimension production possibility set. Of course, if an omitted variable was important in only one of the societies being compared, the model's predictions would be incorrect.

Without training in the "big questions" of economics, an economist may see the movement from below the PPC to on the PPC as a simple matter. Yet that very movement requires incentives. The Soviets were indeed below the PPC. Why? Without markets to direct resources to their best use, there was a huge amount of social waste, of output that failed to materialize. It took economists rather a long time to recall this point. $^{10}$

Thirdly, forgetting past insights can be costly. How many trillion dollars of assets have been destroyed because we

\footnotetext{
${ }^{9}$ For details, see D. M. Levy and S. J. Peart, "Prudence with biased experts: Rating agencies and regulators," www.ssrn.com/abstract=1681609 (2010). ${ }^{10}$ D. M. Levy and S. J. Peart review the celebrated debate, "The socialist calculation debate," in S. Durlauf and L. Blume (eds.), The new Palgrave dictionary of economics online, London: Palgrave Macmillan. http:// www.dictionaryofeconomics.com/article?id=pde2008_S000535
}

forgot what we once knew about the incentives of the ratings agencies?

\section{The Past as Public Good ${ }^{11}$}

How might the fact that it is rather common to find surprising and valuable things in the past be consistent with the lack of remuneration in the history of economics? Blaug (2001) suggests that the surprising nature of the past is evidence that economists are failing to optimize by neglecting the history of economics. Blaug chose to focus on how a scholar uses time for private purposes. His discussion of the Coase Theorem is germane because Stigler believed that Coase's result showed how private and social cost could be equated by bargaining.

Consider the two above accounts of the history of economics. It may be in the interest of the representative economist to know that the "history" contained in the standard account described above, is a "history" entailing a set of "evidence" that supports the historian's original preconceptions. ${ }^{12}$ Nonetheless, there is nothing in the standard reward package in economics as a discipline that provides the incentives for an individual economist to make the considerable investment in scholarship required to find this out.

Traditionally, when economists find a divergence between private and social costs, we propose some sort of intervention on the part of policy makers: they demand more government activity when markets fail to equate private and social costs. They demand less government activity when governments fail to equate private and social costs. And what shall we demand when the rationally choosing economics profession itself fails to equate private and social costs?

The profession does not follow this thought to its conclusion, perhaps because there seems to be a strong belief among economists that we are truth-seekers and so we need not worry overly much about the public goods problem within economics. In econometrics, for instance, the truth-seeking assumption in economics proper seems to explain the otherwise curious lack of a code of econometric ethics. There is, after all, a long tradition of codes of ethics in mathematical statistics, ASA 2000 being only the latest from the American Statistical Association. ${ }^{13}$ Codes of ethics can be viewed as

\footnotetext{
${ }^{11}$ Valuing (and Teaching) the Past. S. J. Peart and D. M. Levy, Journal of Economic Education 36(2005):171-184

${ }^{12}$ For a similar argument in a statistical context, see S. Feigenbaum and D. M. Levy, "The technological obsolescence of scientific fraud," Rationality and Society, vol. 8 (1996): 261-276.

${ }^{13}$ See R. A. Gorlin (ed.), Codes of professional responsibility. Washington: Bureau of National Affairs. This 1100 page compendium of "codes of professional responsibility" indexes professions alphabetically; economics is not among those listed. The question of why there is no code of ethics in econometrics is addressed in D. M. Levy and S. J. Peart, "Inducing greater transparency: Towards the establishment of ethical rules for econometrics," Eastern Economic Journal, vol. 34 (2008): 103-14.
} 
attempts to modify the behavior of people whose interests conflict with others.

The truth-seeking assumption obviates the need for a code of ethics because truth is evidently a pure public good and there can be no difference between what is in our interest and the public interest. But a belief in the truthseeking behavior of others has drastic consequences. When we believe that everyone else is a truth-seeker, and thus the literature will be free from gross, systematic error, we can free ride on the efforts of others. This free riding produces the difference between private and social costs.

The social consequence of yielding much of the responsibility for teaching the history of economics is described in our "Secret History of the Dismal Science" at the online Library of Economics and Liberty. There, we show how economists have been told, and the reading public has largely been convinced, that those who defended markets in the past were callous and hard-hearted. By contrast, opponents of markets such as Thomas Carlyle, John Ruskin and Charles Dickens, have acquired and held onto a reputation for kind-heartedness towards the unlucky among us. Today, that reputation is defended in the face of evidence that suggests that the alternatives to markets put forward by such opponents served to preserve hierarchy. ${ }^{14}$ Without much in the way of competition over the past, this view of history prevails.

Those who study the economists of the Classical period have often been concerned with answering the criticism that markets do not generate enough equality in outcomes. We have neglected to consider those who objected that markets tend to bring about too much equality, too much openness, too much leveling, or too little hierarchical structure. This is the major insight that knowledge of the past debates over the dismal science offers to working economists today.

This is a good moment in which to make the case that undergraduates need to understand the conceptual foundations of markets, reciprocity and exchange and that we need competent people to teach them. One way for students to appreciate the "big questions" that underscore their technical economics classes, is to have them read some of the big books from the past of economics. Adam Smith. T. Robert Malthus. J. S. Mill. Ludwig von Mises. Friedrich Hayek. J. M. Keynes.

So, the time is perhaps more ready than it has been in the last 30 years, for re-grounding economics - indeed, the social sciences broadly construed - in the humanities, for reconnecting history, philosophy, political theory, literature

\footnotetext{
${ }^{14}$ Of course, critics of classical economists may have been wellmeaning, and some may have had the interests of the laboring classes at heart. The point is that the critics shared a world view entailing hierarchy of individuals that in turn legitimized direction for those of lesser ability.
}

and economics. Certainly there is a growing realization that the purely technical training we have offered generations of economics majors (and Ph.D. candidates) has left them with little understanding of the big questions that underscore our reliance on markets and the institutions that constrain market transactions.

There may now be a window of opportunity, one in which we can credibly again make the case for promoting careful study of the big books that underscore any discussions of markets, institutions and self-governance. ${ }^{15}$

One benefit of trade across disciplines is that it leaves room for disciplinary competence. All-too-frequently interdisciplinarity is used to mean quite the opposite, knowing very little about something and then writing and talking about it. But that sort of research may constitute a recipe for giving up real competence in anything. More useful, by contrast, is disciplinary competence and then coming together to discuss a class of problems that interests others whose training is, perhaps, in another discipline. Competition in the space of intellectual commitments, as Smith would argue, is a key to good theorizing. If one is to help teach the teachers of the future, this willingness to discuss views without precommitment and dogmatism is necessary. So alongside Malthus, let students read William Godwin.

The time has come for economists to recognize that they have much to bring to the table, in fact more than this, that an attempt to understand the western liberal tradition which neglects the role of political economists and political economy is lacking in ways that may well prove quite costly (as the financial collapse and the policy responses that followed have revealed). Lionel Robbins, one of the twentieth century's great economists steeped in the tradition of political economy, summarized the importance of knowing our past in his Theory of English Political Economy: "It is no exaggeration to say that it is impossible to understand the evolution and the meaning of Western liberal civilization without some understanding of Classical Political Economy."16

\section{Further Reading}

Blaug, M. 2001. No history of ideas, please. We're economists. Journal of Economic Perspectives, 15, 145-65.

\footnotetext{
${ }^{15}$ This is the approach taken by two interrelated programs: the John Marshall Center for the Study of International Statesmanship, codirected by Gary McDowell and Terry Price; and the Adam Smith program which hosts the Summer Institute for the Preservation of the History of Thought, now in its thirteenth year. At the Summer Institute, graduate students are eager to learn what their economics coursework leaves out

${ }^{16}$ L. C. Robbins, The theory of economic policy in English classical political economy, (London: Macmillan, 1952).
} 
Carlyle, T. 1849. Occasional discourse on the Negro question. Fraser's Magazine for Town and Country, 40, 670-79.

Ekelund, R. B., \& Hébert, R. F. 1990. A history of economic theory and method (3rd ed.). New York: McGraw-Hill.

Feigenbaum, S., \& Levy, D. M. 1996. The technological obsolescence of scientific fraud. Rationality and Society, 8, 261-276.

Goodwin, C. 2008. History of economic thought. In S. Durlauf and L. Blume (Eds.), The New Palgrave dictionary of economics online. London: Palgrave Macmillan. http://www.dictionaryofeconomics.com/article?id=pde2008 H000174.

Heilbroner, R. L. 1961. The worldly philosophers. New York: Simon and Schuster.

Levy, D. M. 2001. How the dismal science got its name: Classical economics and the ur-text of racial politics. Ann Arbor: University of Michigan Press.

Levy, D. M., \& Peart, S. J. 2001-2002. The secret history of the dismal science. http://www.econlib.org/library/Columns/ LevyPeartdismal.html.

Levy, D. M., \& Peart, S. J. 2010. Prudence with biased experts: Rating agencies and regulators. www.ssrn.com/abstract $=1681609$.

Levy, D. M., \& Peart, S. J. 2011. Soviet growth and American textbooks: An endogenous past. Journal of Economic Behavior and Organization, 78, 110-25.

Marshall, A. 1907. The social possibilities of economic chivalry. Economic Journal, 17, 7-29.

Mill, J. S. 1850. The Negro question. Fraser's Magazine for Town and Country, 41, 24-31.

Peart, S. J. 1994. The education of economists: Teaching what economists do. Journal of Economic Education, 25, 81-87.
Peart, S. J., \& Levy, D. M. 2005a. Valuing (and Teaching) the Past. Journal of Economic Education 36, 171-184.

Peart, S. J., \& Levy, D. M. 2005. The "Vanity of the philosopher": From equality to hierarchy in post-classical economics. Ann Arbor: University of Michigan Press.

Robbins, L. C. 1952. The theory of economic policy in English classical political economy. London: Macmillan.

Samuelson, P. A. 1948-1980. Economics: An introductory analysis. New York. McGraw-Hill.

Smith, A. [1776] 1904. An inquiry into the nature and causes of the wealth of nations. Edited by Edwin Cannan. http://www.econlib.org/library/Smith/smWN.html

Sandra J. Peart became the fourth dean of the Jepson School of Leadership Studies in 2007. She is a co-director of the annual Summer Institute for the Preservation of the History of Economic Thought. Her special expertise is in the history of economic thought and political economy, especially in the context of ethical leadership. Dr. Peart has authored or edited six books, many with David M. Levy, a professor of economics at George Mason University, including The Street Porter and the Philosopher: Conversations on Analytical Egalitarianism. She is the author of numerous journal articles on topics such as ethics and economics, rationality, utilitarianism, race and eugenics, the transition to "modern" economics, and leadership in pubic goods experiments. This article was written for a conference co-sponsored by the Manhattan Institute and Society. Grateful acknowledgement is given to the Marilyn G. Fedak Capitalism Project for its support. 